\title{
Novel cellular and post-genomic technologies in the treatment of glioblastoma multiforme (Review)
}

\author{
IGOR BRYUKHOVETSKIY ${ }^{1}$, ANDREY BRYUKHOVETSKIY ${ }^{1}$, \\ YURI KHOTIMCHENKO $^{2}$ and POLINA MISCHENKO ${ }^{1}$ \\ ${ }^{1}$ Laboratory of Molecular and Cellular Neurobiology, School of Biomedicine; and \\ ${ }^{2}$ School of Biomedicine, Far Eastern Federal University, Vladivostok 690091, Russian Federation
}

Received July 30, 2015; Accepted September 17, 2015

DOI: $10.3892 /$ or.2015.4404

\begin{abstract}
Glioblastoma multiforme (GBM) is one of the most aggressive brain tumors. The majority of modern treatment methods for GBM are not sufficiently effective with a median survival varying from 9 to 14 months. One of the main reasons for the therapeutic resistance of GBM is attributed to cancer stem cells. Pharmaceuticals that can effectively eliminate cancer stem cells do not exist. Experimentally, we have shown that cancer stem cells can be specifically affected to arrest adhesion, proliferation and migration, and other key functions. The main target of this therapy involves membrane intracellular signaling pathways of cancer stem cells that are not subject to neoplastic transformation. An effect on such a complex target requires the development of innovative biotechnological approaches. The research analysis of modern approaches towards creating biomedical drugs for treating cancer stem cells of glioblastoma multiforme is based on advances in the latest cellular and post-genomic technologies. The combination of targeted therapy with regulation of the key functions of cancer stem cells using cell systems with a remodeled proteome is suggested.
\end{abstract}

\section{Contents}

1. Introduction

2. Existing methods of glial brain tumor treatment

3. Concept of cancer stem cells

4. Theoretical prerequisites for using cell and post-genome technologies for treating glioblastoma

Correspondence to: Dr Igor Bryukhovetskiy, Laboratory of Molecular and Cellular Neurobiology, School of Biomedicine, Far Eastern Federal University, 8 Sukhanova Street, Vladivostok 690091, Russian Federation

E-mail: igbryukhovetskiy@gmail.com

Key words: glioblastoma multiforme, survival rate, cancer stem cells, stem cells, cell technologies, post-genomic technologies
5. Cell and post-genome technologies in the complex treatment of glioblastoma multiforme

6. Conclusion

\section{Introduction}

Cancer is a fatal disease and has created an urgent challenge for humankind. Malignant tumors are one of the leading causes of mortality in the majority of the world's countries, being slightly behind cardiovascular diseases among seniors and almost at the same level with infectious diseases and injuries among young patients of an active working age (1).

The main sites contributing to the oncologic mortality rate are the lungs, breast, colon and prostate $(1,2)$. Usage of new generation targeted chemotherapeutic agents has helped to prolong the lives of patients with solid tumors in economically developed countries (3). However, this success has not been extended to the treatment of glial brain tumors.

Glioblastoma multiforme (GBM) or grade IV astrocytoma according to the World Health Organization classification is the most widespread, highly invasive primary glial brain tumor that accounts for more than $50 \%$ of all primary brain tumors and $20 \%$ of all intracranial neoplasms. The frequency of diagnosis is 4.65-5.26 cases/100,000 people, while only in the US more than 17,000 new cases are diagnosed each year. The treatment of GBM patients usually involves tumor removal, radiotherapy and chemotherapy. The prognosis is not promising. If patients with glioblastoma follow all procedures of the modern complex treatment, the median survival is 16.2 months for patients 20-44 years of age, 7.9 months for patients 45-69 years of age, and 3.2 months for patients over 70 years of age $(5,6)$.

One of the main reasons for the therapeutic resistance of GBM is attributed to cancer stem cells (CSCs). There are no pharmaceutical means for effective elimination of these cells. In vitro and in vivo experiments have shown that CSCs could be affected by targeted treatment in order to block adhesion, proliferation and migration as well as some other key functions. The main goal of this therapy is to reach membranous targets of intracellular signaling pathways of CSCs that have not been affected by neoplastic transformation. Stimulating such a difficult target requires creating radically innovative 
biotechnological approaches relevant to the complexity of the object. The key methods of dealing with this issue include application of cell and post-genomic technologies. The main focus of this review is to organize the scientific and technical information on the creation and methodology of using cell and post-genomic technologies in the complex treatment of primary brain tumors.

Materials used were scientific and technical studies, patents and current literature on the topic available in the Web of Science, Scopus and PubMed databases.

\section{Existing methods of glial brain tumor treatment}

The current standard of treating malignant tumors includes a unified complex of procedures, such as tumor removal, systemic chemotherapy and radiotherapy (7). Surgical treatment must be extensive and radical. If the tumor is located deep in the brain matter or close to vital centers of the brain stem, it requires the use of high-precision neurosurgical equipment or modern radiosurgical systems $(8,9)$.

Traditional radiotherapy includes 25-30 fractions of X-ray treatment for 5-6 weeks. The frequency of treatment is 5 times weekly with a dose of 1.8-2.0 Gy using three-field arrangement. The life expectancy is correlated with a total boost dose of the amount up to $60 \mathrm{~Gy}$ (10). Further increase in the dose is limited by the development of radiation necrosis $(11,12)$. There is an opinion that total brain irradiation with $50 \mathrm{~Gy}$ helps to prevent relapse of glioblastoma although a systematic irradiation with 50 Gy for 3-5 years leads to radiation damage of the CNS and inevitable mental disability. In case of a favorable result, a patient may be seriously disabled with a severe post-radiation intellectual-mnestic and neurological disorder (13-15).

Temozolomide is usually chosen for glioblastome multiforme treatment (16). In addition, PVC drug combination [procarbazine, lomustine (CCNU), vincristine] is effective, while alternative methods include cyclophosphamide (CAP; doxorubicin, cisplatin) and a combination of lomustine (CCNU), doxorubicin and teniposide. Treatment is used after dehydration and together with corticosteroids and symptomatic medication (17-19). Bevacizumab is currently the most widely used targeted medication. The effectiveness of chemotherapy ranges from 20 to $60 \%$ (20).

Partially, the first stage of standard brain tumor treatment is effective. As a rule, this stage is followed by a 'clean slate' in the disease progression. Relapse may take the form of neurological deficit and continuation of tumor growth that usually is located in the tumor bed and occurs in $95 \%$ of cases in 7-20 months after the surgery $(4,6)$. GBM relapse requires a second surgery and X-ray treatment or extended chemotherapy if radiotherapy is not possible. Targeted therapeutic methods used for GBM have not been proven to have a significant influence on survival rates for this type of patient.

Thus, traditional treatment of CNS tumors is based on the classic principles of tumor treatment and is concentrated on removing cancerous cells. The majority of modern methods and techniques have almost zero effect on the CSCs that are believed to be the main cause of glioblastoma therapeutic resistance.

\section{Concept of cancer stem cells}

The term 'CSC' is an artificial product of experimental medicine in a way. The distinguishing feature of these cells is their ability to trigger tumor creation when implanted into experimental animal bodies even in microscopic quantities. Originally these cells were identified in leucosis, breast cancer and gliobastoma (21). Characteristics of CSCs can be found in $\mathrm{CD}_{133}{ }^{+}$cells of glioblastoma, $\mathrm{ESA}^{+} / \mathrm{CD} 44^{+} \mathrm{CD} 24^{-/ \text {low }}$ of breast, $\mathrm{CD}_{4} 4^{+}$of prostate cancer, and $\mathrm{ESA}^{+} / \mathrm{CD} 44^{+} \mathrm{CD} 24^{-}$of pancreatic cancer, and side population of cells without Hoechst pigment in the case of ovarian cancer (22-24).

The question of the origin of CSCs still has no definite answer. They are highly probable to appear after disruption of tissue mechanisms that control clonogenic cell proliferation that causes the possibility to reverse transitions from normal to altered or modified cell phenotype. Furthermore, carcinogens influence oncogene activation, suppress tumor-suppressor genes, and continues the damage of epigenetic control of gene expression. As a result, there appears to be a clonal version of the cells having maximum autonomy, individuality and complete independence from their medium. These cells develop mechanisms that prevent depletion of telomeres and become immortalized giving them a strategic advantage in their fight for survival. This concept was mainly described in the studies of Duesberg et al who believed carcinogenesis to be a type of species formation (25).

The idea regarding cancer as being a stage of species evolution instead of just a disease was expressed by Julian Huxley and some evolutionary biologists in 1956. The theory of species formation that is a logical offspring of the mutation theory partially explains the mechanisms of the appearance of CSCs. Yet, it lacks argumentation for the fact that this type of cell has both the ability of infinite self-renewal and production of different cell types depending on the medium in which they have been placed.

According to a second version, CSCs appear to be the result of the neoplastic transformation of normal stem cells. Neurogenesis in an adult brain of mammals was described for the first time by Altman in the 1960's (26). Thirty years later, neural stem cells (NSCs) were extracted from an adult brain of a mammal and can be considered as the most significant breakthrough of 20th century neurobiology (27). Originally NSCs were discovered in the subependymal zone in the lateral ventricles of adult mice and the rat brain and were later extracted from the hippocampus of adult primates and humans. NSCs are able to constantly regenerate, migrate and produce cells of different types (28). The typical germinal zone of an adult brain also contains neural progenitor cells that are direct descendants of NSCs and have the highest proliferative activity of germinal zone cells $(29,30)$.

Neural stem and progenitor cells are the most probable source of GBM CSCs. This is indicated by their similarity on the basis of the main immunocytochemical marker of the cell surface (21) and identical nature of $63.5 \%$ of the NSC and CSC proteome in human glioblastoma (31). We cannot deny the experimental data. The transfer of Myc and Ras oncogenes into nervous system cells causes the creation of invasive tumors only after they have entered NSCs (32). The NSC karyotype is very unstable, and in the case of long cultivation these cells 
accumulate chromosomal anomalies that become replicated in the following passages. There have been registered cases of trisomy of chromosomes 7, 12, 17, 19 and X, different forms of aneuploidy, an elevated level of telomerase expression, and cases of spontaneous neoplastic transformation of NSCs after a series of in vitro passages (33-35).

It is obvious that constant proliferation during a lifetime of an individual results in the accumulation of mutations that become a starting point for tumor development. Another possible mechanism of CSC development can be reprogramming of NSCs by oncogene expression products as a result of their interaction with pathologically altered cells, elements of the cell matrix (Fig. 1) or during cell fusion $(36,37)$.

CSCs have a system-building role. They organize processes of invasive growth, secure formation of timorous blood, lymph and nervous networks, interact with fibroblasts and vascular endothelium cells creating a barrier that protects cancer cells from chemical medication. CSCs are able to restore damaged DNA using $\mathrm{CD} 33^{+}$cells to produce a special ferment called $\mathrm{O}^{6}$-methylguanine-DNA-methyltransferase or MGMT factor. This mechanism along with activation of ATM, Rad17, Chk2 and Chk1 proteins allows a cell with a damaged genome to pass a basic stage of the cell cycle and proliferate actively, resulting in tumor relapse after its removal. The ability of the rapid restoration of the neoplastic population totally depends on the amount of CSCs (38-40).

The amount of CSCs in a tumor is a very important and dynamic factor. According to the literature, the number of CSCs in GBM tissues varies between 0.1 and $11 \%$ and can reach up to $50 \%$ of the cell population. This partially explains its aggressiveness $(41,42)$. This parameter is one of the main characteristics of the tumor condition. Research by Shen et al showed that $\mathrm{CD}_{133^{+}}$phenotype cells (main CSC marker) constitute $87.2 \%$ of the glioma C6 cell population that can be extracted from glioma spheres freely moving in vitro. The CD133 marker can reveal either the CSC potential of a cell or its epithelial nature, or both. Taking into consideration the location of NSCs, noting this marker in C6 cells is not unexpected. At the same time the number of GFAP-positive cells does not exceed $0.95 \%$. After the cells are attached to the surface, the amount of $\mathrm{CD}_{133^{+}}$cells is reduced to $30.2 \%$, while the number of GFAP-positive cells reaches 50.1\% (43).

In an in-house study, $96 \%$ of C6 glioma cells extracted from freely circulating glioma spheres became stained by antibodies against nestin. After adhesion to the substrate the number of nestin-positive cells was reduced to $52.5 \%$. Nestin is one of the most important stem cell markers (44). Adhesion to the substrate is clearly an important mechanism of regulating a number of CSCs, otherwise CD133 and nestin expression is mostly characteristic of migrating NSCs that suggests the hypothesis of transforming NSCs into CSCs in the conditions of atypical influence of stromal or cellular microenvironment.

CSCs are a main target in GBM treatment. The majority of immunocytochemical markers of these cells such as CD133, nestin, L1CAM (CD171), CD15, CD44, CD81, TPT1 and A2B5 (45-47) have been discovered and the main signaling pathways that they use for proliferation such as Notch, Hedgehog-Gli, RTK-Akt, BMPs/TGF $\beta$, Wnt- $\beta$-catenin and STAT3 have been identified $(21,48)$. However, there is no medication for the effective elimination of these cells. The

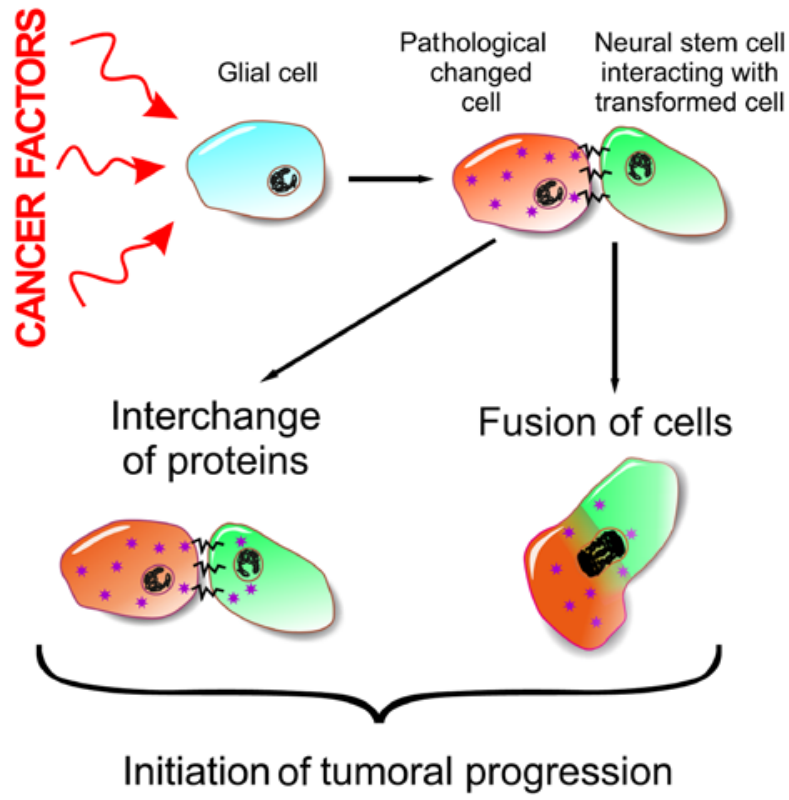

Figure 1. The mechanisms of the interaction between stem cells and pathologically changed brain cells (direct reprogramming of stem cells by expression of oncogene protein or cell fusion of the two cell types.

possibilities of affecting certain target characteristic of these cells are being studied. For example, sunitinib affects the MAPK pathway. Rapamycin inhibits the OPI3K/Akt pathway, cyclopamine blocks the SHH pathway, while there are still no effective and safe medication for suppressing Wnt signal transduction cascade of CSCs (49). Effective drugs blocking the adhesion mechanisms of CSCs have not yet been developed.

Thus, CSCs are a crucial element in glioblastoma development, a key moderator of invasive growth processes and a universal form of tumor cell survival. Various arguments suggest that CSCs of primary brain tumors originate from NSCs of the human brain, although these suggestions support alternative ideas. A large number of CSCs indicates a very bleak prognosis. Stem features of cells (cell rounding, disappearance of some surface markers, disruption of intercellular contacts) appear to be a fundamental survival mechanism for a cancer cell that requires development of completely new methods for managing this process.

\section{Theoretical prerequisites for using cell and post-genome technologies for treating glioblastoma}

Stem cells have been successfully used in oncology for more than 50 years. Their usage in the complex treatment of malignant tumors in the 1960 became a breakthrough in science. Today they are widely used in post-chemotherapy for reconstructing the hematopoietic system, treating immunodeficiency, creating anticancer vaccines, cytotoxic lymphocytes and dendritic cells. Stem cell transplants have become one of the central practices in the treatment of serious diseases and CNS disorders. The neurotrophic and neoplastic effects of stem cells on pathologically modified nerve tissue have been proven, while further plans for their application are connected with brain tumor treatment. Key mechanisms of the anticancer effect of stem cells include their targeted migration to the 
tumor nodule and intercellular interaction in the neoplasia area.

The phenomenon of stem cell-targeted migration to the area of trauma, ischemic or neoplastic damage of the brain have been closely studied by neurobiologists. Our research group published a number of experimental and theoretical studies based on the subject. Numerous scientists treat this phenomenon only as a repair mechanism. Researchers have identified 80 cytokines and $>20$ types of receptors controlling this process. The key role here is attributed to the interaction of stromal cell-derived factor (SDF-1 $\alpha$ ) with the CXCR4 receptor of the stem cell membrane. The importance of stem cell factor (SCF), hepatocyte growth factor (HGF), vascular endothelial growth factor (VEGF), high-mobility group protein B1 (HMGB1), monocyte chemotactic protein 1 (MCP1) and other ligands released by damaged tissues has been proven (50). It is traditionally believed that the main sources of cytokines are damaged neurons, astrocytes, microglial cells and retrograde elements of the intercellular matrix released into blood vessels.

However, experimental data show that the original source of cytokines can be tumor cells themselves $(51,52)$. Having autonomy, they can synthesize their own cytokines. The scientific literature has a detailed description of neuroepithelial tumors able to produce tenastin, fibronectin, laminin and collagen that change the direction of stem cell migration (53). One of the key parameters in glioblastoma biology is hypoxia that causes excessive production of hypoxia-induced factor (HIF) molecules. They are the main inducing substances for producing SDF-1 $\alpha$, SCF, HGF and other cytokines that stimulate stem cell migration (54).

Cytokines cause stem cells to migrate towards cancer cells. In a study by Moore et al, it was suggested that the absolute majority of $\mathrm{CD} 34^{+}$stem cells was found in the neoplastic tissue after being injected in an animal with a brain tumor (55), and this fact was completely proven by the research (Fig. 2). The above mentioned finding allows considering the phenomenon of targeted migration of stem cells to neoplastic focus to be the most important mechanism of tissue homeostasis regulation (56).

Aboody et al reported a molecular adhesion effect (57) which represents the unique ability of stem cells to follow a cancer cell into the brain parenchyma on its cytokine trail, reach the neoplastic cell and attach itself to it by straddling it like a jockey. This mechanism opens vast possibilities for the targeted cell therapy of glial and metastatic brain tumors.

The majority of glioblastoma cells infiltrating the brain parenchyma during its invasive growth are in interphase. These cells are insusceptible to traditional cytostatic agents, while the hypoxic metabolism neutralizes the effects of radiation. Molecular adhesion allows the direct delivery of ferments metabolizing inactive substances to cytotoxic matter, nanoencapsulated medication used for photothermal ablation, therapeutic genes and oncolytic viruses (58-60).

However, the phenomenon of targeted migration cannot be viewed only from the standpoint of addressed delivery. Stem cells will undoubtedly find a cancer cell once being introduced into a blood vessel, implanted vertically or incorporated into biopolymer matrices filling the tissue deficiency remaining after tumor removal. In the latter case, being conjugated with immunoliposomes (61), they use the shortest way to transport therapeutic agents to the remaining cancer cells infiltrating the brain parenchyma, reaching the most hypoxic zones and creating the maximum concentration of the therapeutic agents to minimize side-effects of the treatment and reinforce the cytotoxic effect.

Upon reaching the neoplasia zone, stem cells become attached to cancer cells and interact with them (Fig. 3). Mechanisms of intercellular communication include exchange of specific regulatory proteins, activation of cell surface receptors, bystander effect, stimulation of inflammatory response, arrest of G1 phase cancer cell cycle and reprogramming of tumor cells via cytoplasmic transcription factors during the fusion of stem and cancer cells (62).

Accumulation of healthy stem cells in the neoplasm zone inhibits tumor development which has been experimentally proven many times. If the ratio of stem to cancer cells is $2: 1$, the proliferation speed of the latter drops significantly, while when there are a large number of stem cells, cancer cell proliferation stops (63-65). In the case of combined cultivation of hematopoietic stem cells (HSCs) $\mathrm{CD} 34^{+} \mathrm{CD} 45^{+}$with $\mathrm{C} 6$ glioma there is an active exchange of molecules that is proven by the fact of cancer cell accumulation of pigments connected with HSC cytoplasmic proteins. This phenomenon is also observed in the cultivation of lung cancer cells and breast cancer cells with HSCs (Fig. 4A-D). The mechanisms of this phenomenon probably include creation of structural and functional syncytium and cell fusion effect between interacting cells (66).

Cell fusion is a fundamental biological process. This mechanism enables the exchange of both regulation and defective proteins $(67,68)$. Serious disruptions of DNA methylation significantly destabilize a genome, while microRNA exchange resulting from mixing cytoplasm suppresses onco-suppressor gene expression (for instance, $\mathrm{miR}-34 /$ deactivates $c$-Met gene, miR-146a/gene deactivates Notch gene, miR-7/gene EGFR, miR-128/gene Bmil) and stimulates oncogene activity (69-71). This mechanism needs to be studied. Yet, it is already clear that the stem cell proteome profile modification related to regulatory protein production allows us to create a cell biological drug for inhibiting the activity of glioblastoma cells located deep in the brain parenchyma and some metastatic tumors.

At important inducer of cancer cell elimination is tumor necrosis factor (TNF). This family includes 19 proteins that have a function of ligand for 29 receptors. Receptors of the superfamily interact with adaptor proteins including TRADD, TRAF, RIP that define a cell response to cytokine activation, for instance, stimulation of apoptosis or inflammation. Currently, there are methods of addressed delivery of TRAIL, S-TRAIL proteins right into the cancer cells via using stem cell potential (72). There are methods of HSC modification by incorporating therapeutic genes into them to induce TNF production $(73,74)$. The important feature is the ability of TNF to stimulate the production of granulocyte colony-stimulating factor that mobilizes stem cells from their repository in the bone marrow, thus stimulating their migration to the neoplasia zone (75).

The 'Bystander' effect is a special case of inductive interaction between cells. The main principle of this effect involves triggering key functions in one of the interacting cells. This phenomenon is frequently observed in radiology when the death of a cell having received a lethal radiation dose 

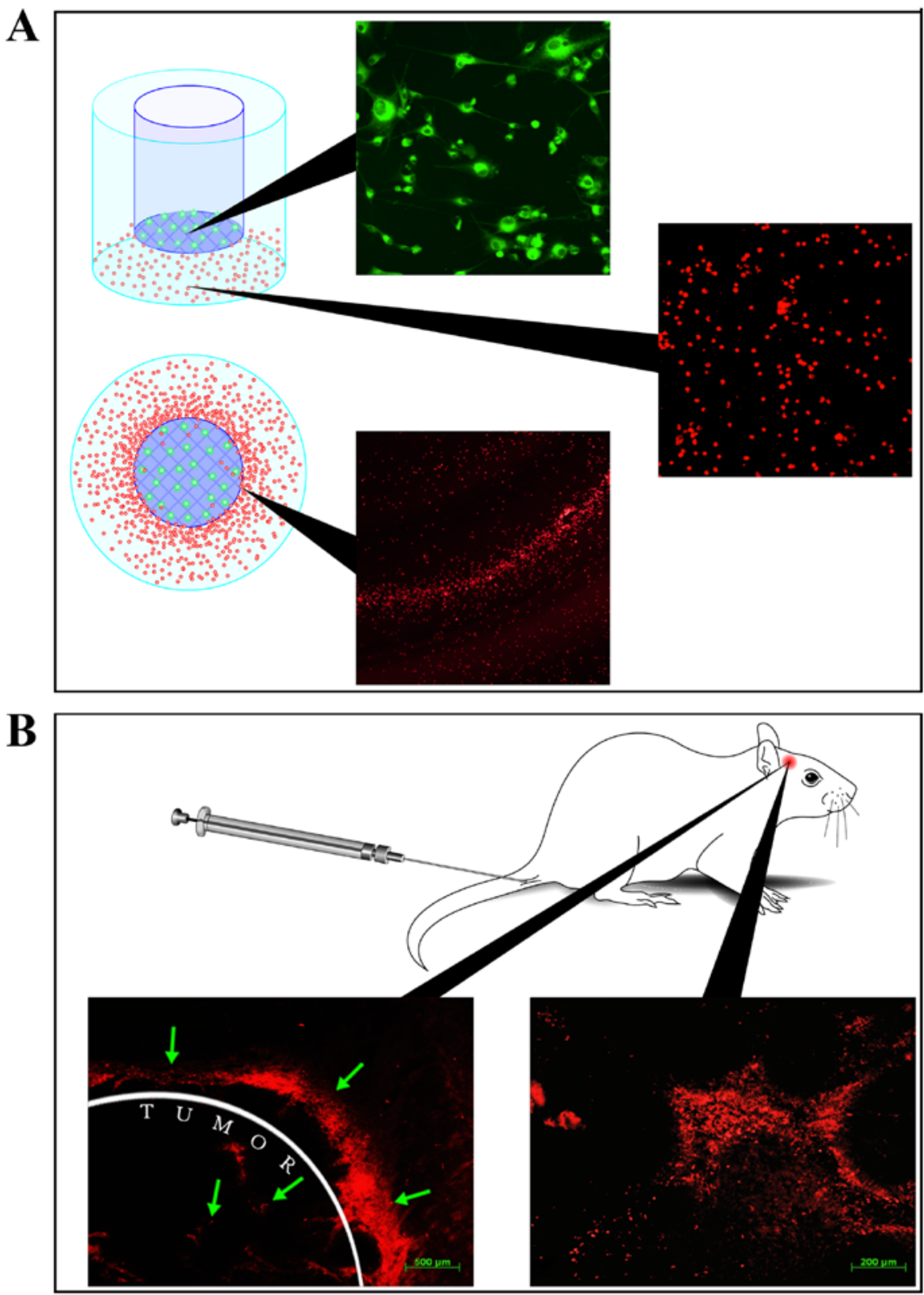

Figure 2. Experimental scheme. (A) Hematopoietic stem cells with a CD34+ phenotype (stained CellTracker ${ }^{\mathrm{TM}}$ Red CMTPX Dye-red) formed a shaft around the insert with glioblastoma U87 cells (stained Vybrant ${ }^{\circledast}$ CFDA SE Cell Tracer-green) and penetrated through the pores (8.0 $\mu \mathrm{m}$ diameter) of the insert. (B) After injection into the central tail vein of glioma-bearing rats, hematopoietic stem cells migrated to the tumor and accumulated in the areas of necrosis.
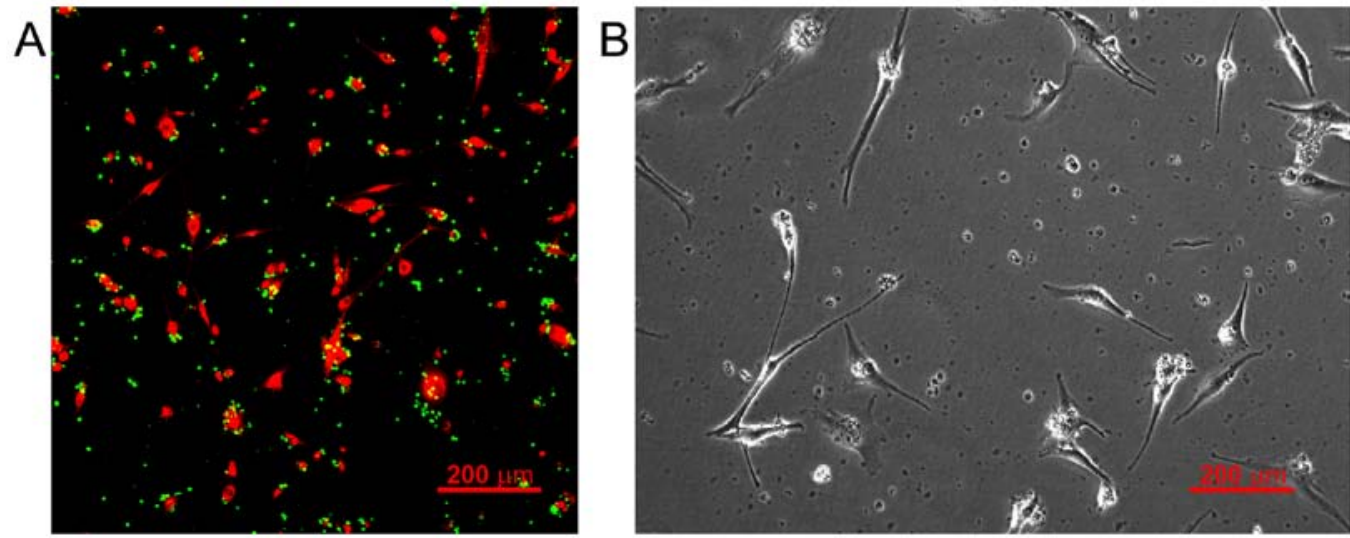

Figure 3. Interaction of cells in co-culture. (A) Interaction of hematopoietic stem cells with a CD34+ phenotype (stained Vybrant ${ }^{\circledR}$ CFDA SE Cell Tracer-green)

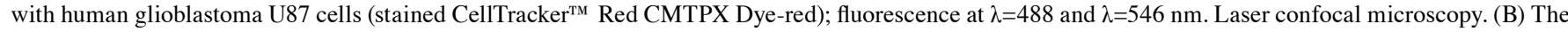
adhesion of hematopoietic stem cells with a CD34+ phenotype to human glioblastoma U87 cells in co-culture. Phase contrast. 

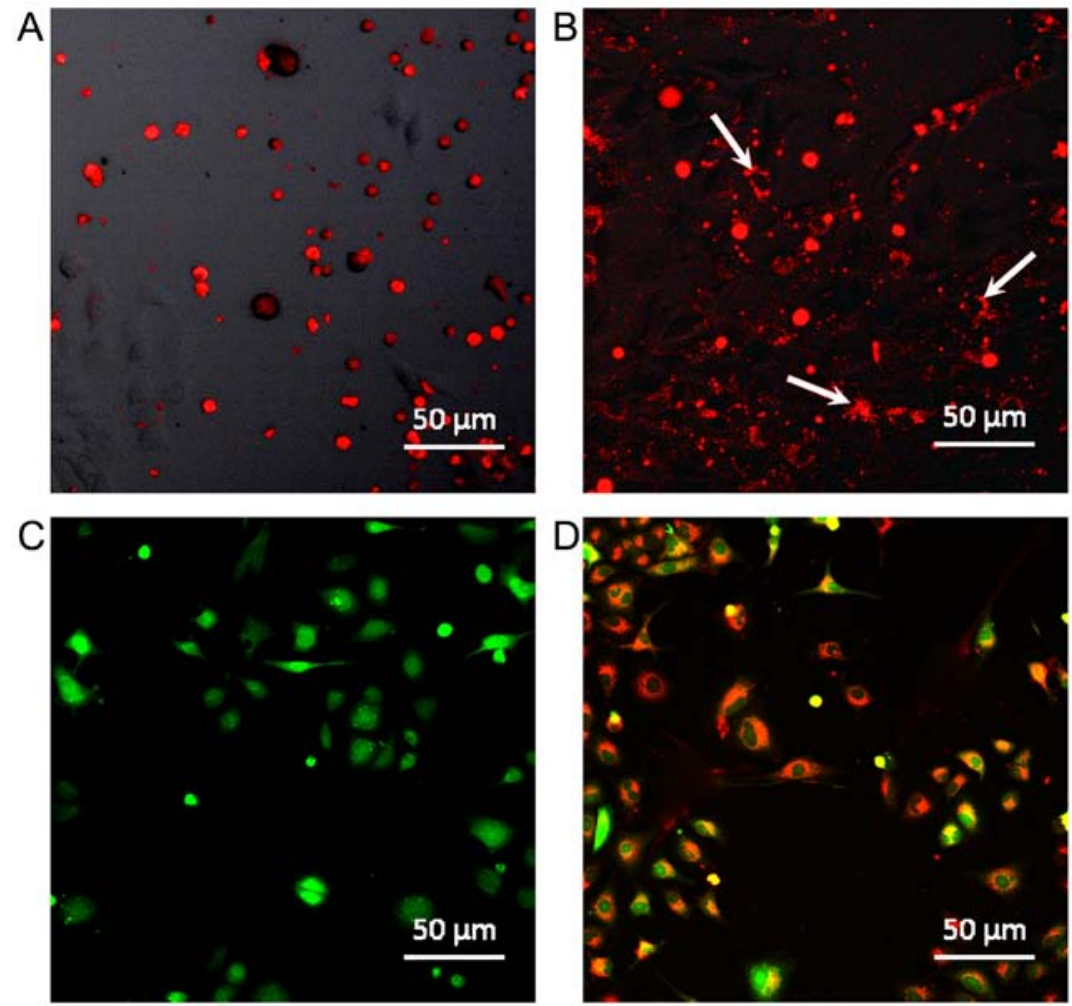

Figure 4. Interaction of cells in co-culture. (A) Interaction of hematopoietic stem cells with a CD34+ phenotype (stained CellTracker ${ }^{\mathrm{TM}}$ Red CMTPX Dye-red) with glioma C6 cells (not stained). Laser confocal microscopy $(\lambda=546 \mathrm{~nm})$. (B) Originally unstained glioma C6 cells accumulated the dye from hematopoietic stem cells (stained CellTracker ${ }^{\mathrm{TM}}$ Red CMTPX). Laser confocal microscopy $\left(\lambda=546 \mathrm{~nm}\right.$ ). (C) Lung adenocarcinoma A549 cells (stained Vybrant ${ }^{\circledR}$ CFDA SE Cell Tracer-green). Laser confocal microscopy $\left(\lambda=488 \mathrm{~nm}\right.$ ). (D) Lung adenocarcinoma A549 cells (originally stained Vybrant ${ }^{\circledR}$ CFDA SE Cell Tracer-green) in co-culture with hematopoietic stem cells with a CD34+ phenotype (originally stained CellTracker ${ }^{\mathrm{TM}}$ Red CMTPX Dye-red). After $24 \mathrm{~h}$ of co-culture, we observed a double fluorescence at $\lambda=488$ and $\lambda=546 \mathrm{~nm}$, which was caused by the transition of cytoplasmic proteins. Laser confocal microscopy.

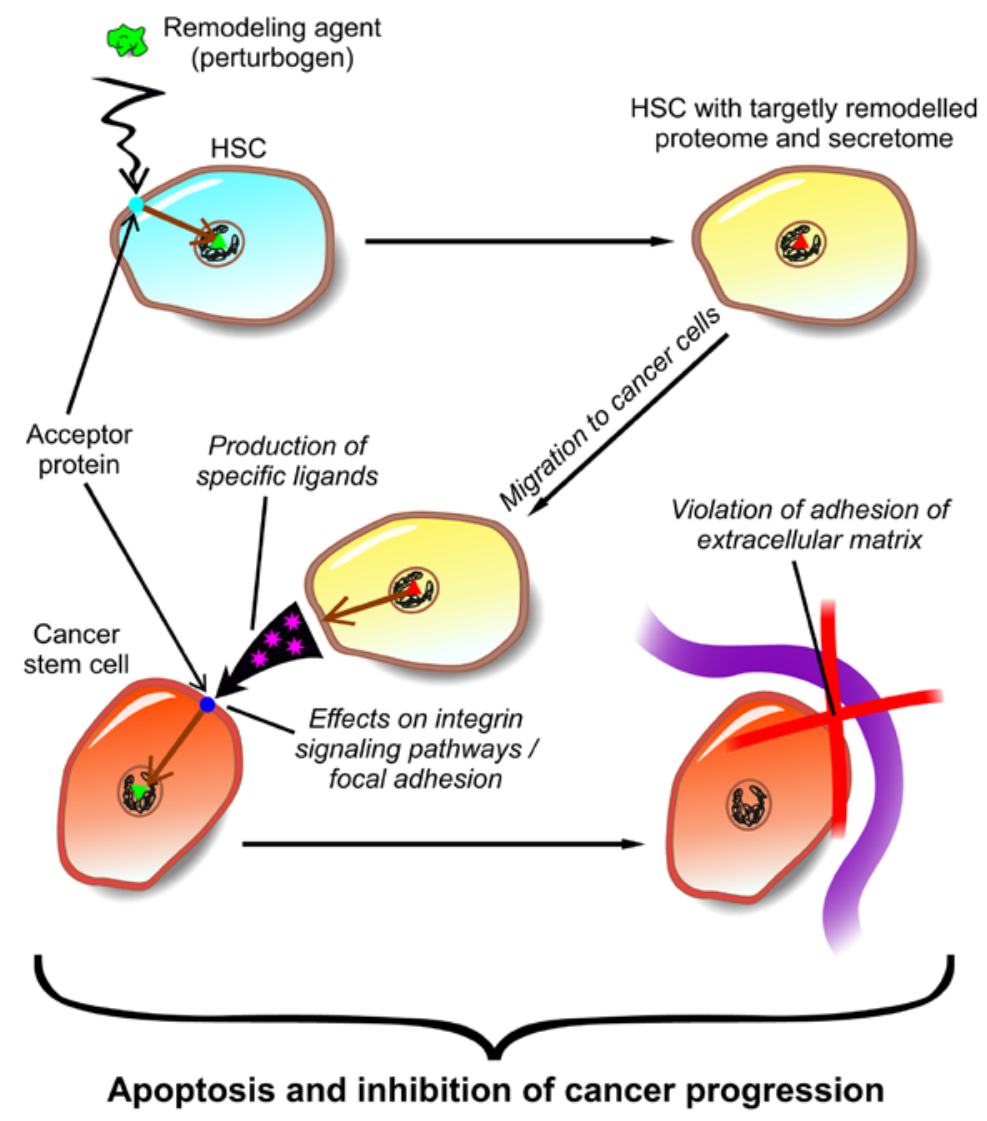

Figure 5. Prospective scheme of the proteome-based cell therapy of glioblastoma. 
is followed by suspended death of the tumor cells closest to it. Radiation stimulates production of IL-1, IL-2, IL-6, IL-8, TNF $\alpha$ and TGF $\beta$ by cells. The mechanism opens the possibilities of creating cellular systems with induced apoptosis that can transfer destructive influence to the cancer cell (76-78).

Thus, the advances in cellular biology and post-genome technologies even now allow the creation of totally new methods of glioblastoma treatment. However, CSCs have very strong repair mechanisms. It is highly probable that selective treatment slows down tumor development, but later CSCs will react creating new resistant cell clones that will provoke a relapse. This situation requires the development of specific methods for managing the key functions of CSCs.

\section{Cell and post-genome technologies in the complex treat- ment of glioblastoma multiforme}

A disadvantage of the existing strategies for the treatment of malignant tumors is having an ideal goal of destroying all neoplastic cells. This is unrealistic due to the ideal nature, and it is particularly true in the case of non-encapsulated tumors of the nervous system. Glioblastoma is an autonomous dynamically changing structure with the ability to adapt in response to growing intensity of treatment procedures. One reaction for adapting to drugs and radiation is an increase in the number of CSCs.

Neurosurgery is able to solve a number of problems at the same time. It reduces intracranial hypertension, eliminates a large part of cancer cells, including their clones, and this activates the proliferation processes of the remaining pools and makes them vulnerable to medication. In addition, surgery also breaks the integrity of the hematoencephalic barrier that increases the spectrum of applicable medication (80).

Further chemotherapy mostly is based on a standard procedure that has been previously described. A key breakthrough is cytokine therapy designed to disintegrate the interaction between tumor cells and the local microenvironment; excessive expression of epidermal growth factor receptor (EGFR) is characteristic of $40 \%$ of GBM. In order to influence this target, drugs such as gefinitibum (Iressa ${ }^{\circledR}$ ), erlotinib (Tarceva ${ }^{\circledR}$ ) and lapatinib (Tyverb ${ }^{\circledR}$ ) have been suggested. Platelet-derived growth factor (PDGF) is one of the major ligands in GBM biology. To suppress PDGF, tandutinib (MLN518) and sunitinib (Sutent ${ }^{\circledR}$ ) are suggested. These drugs directly suppress tyrosine kinase signaling and block proliferation, migration and anti-apoptosis mechanisms in cancer cells (81-83).

Hypoxia is a key parameter of GBM biology, and this offers certain clinical potential for the use of such drugs as inhibitors of the signaling pathway PI3K/AKT/MTOR that include temsorolimus (Torisel ${ }^{\circledR}$ ) and everolimus (Afinitor ${ }^{\circledR}$ ). These drugs reduce HIF and VEGF levels in cancer tissues and helps to suppress the development of blood vessels and reduces the ability of CSCs to adapt in a hypoxic media (84-86).

One widespread approach is the use of immunotherapy, and it is not unreasonable. Since a person normally has up to $500,000\left(10^{5}\right)$ cancer cells, a patient with pre-cancer has $\sim 1$ billion $\left(<10^{9}\right)$ of them, while a patient with a malignant tumor has more than a billion cells. The healthy body has these cells under control via a natural regulatory system. Surgery helps to reduce the amount of cancer cells up to $10^{9}$, while radiation, radio and chemotherapy allow the reduction of cancer cells from $10^{9}$ to $10^{7}$.

Sanogenetic abilities of our immune system may be activated only if the number of cancer cells does not exceed $10^{5}$. A gap between sanogenetic abilities of the immune system and therapeutic possibilities of classic antitumor treatment is $\sim 2$ orders (from $10^{5}$ to $10^{7}$ cancer cells). Researchers have high hopes for immune therapy in order to eliminate those remaining $10^{2}$ cancer cells, and in some cases it may prolong the life of neuro-oncological patients.

However, using even the most modern methods of cytoreductive therapy without targeting CSCs will not have the expected outcome. If we treat the 'stem' nature of cancer cells as a reason of their survival, than there is a reasonable assumption that a tumor will increase the number of CSCs in order to fight the treatment. Radiation induces the selection of cell clones that are more resistant to hypoxia. Low partial pressure of oxygen prevents the creation of free radicals that neutralize the effect of radiotherapy. With partial pressure of oxygen being between 0.01 and $5 \%$, cancer cells experience cell cycle arrest of the $\mathrm{G} 0 / 1 / \mathrm{Gs}$ phase preserving their invasive potential and making them resistant to cytostatic chemotherapy. In their turn, a large number of CSCs initiates invasive growth mechanisms very rapidly after normalization of external conditions (87-89).

In this respect, the use of cell and post-genome technologies may include specific mechanisms of interaction between CSCs and the cell matrix. The result of NSC and CSC comparative proteome mapping of glioblastoma U87 cells concluded that a pathway of focal adhesion in CSCs in glioblastoma was not affected during neoplastic transformation (31) and can be used for treatment targeted at disintegration of the CSC-extracellular matrix bond (Fig. 5).

A signaling pathway of focal adhesion starts with transferring a signal to the cell by growth factors (EGF, FIGF, HGF, IGF1, PDGFA, PDGFB, PGF, PDGFC, PDGFD, VEGFA, VEGFB and VEGFC) and proteins of the extracellular matrix (lamenines, fibronectin FN1, chondroadherin CHAD, cartilage oligomeric matrix protein COMP, integrin-binding sialoprotein IBSP, tenascins TNC, TNN, TNR, TNXB, reelin released by phosphoprotein 1, thrombospondins THBS1, THBS2, THBS3 and THBS4, vitronectine and von Willebrand factor). The external side of the plasmatic membrane is a site for transferring signals via integrins, caveolins and tyrosine kinase receptors (EGFR, ERBB2, FLT1, FLT4, IGF1R, KDR, MET, PDGFRA and PDGFRB). This set of protein targets helps to influence the CSC adhesion processes in a direct way. Correspondingly, a whole set of protein targets is obtained allowing to interfere with the adhesion processes of CSCs $(31,90,91)$.

Modification of the transcriptomic profile of autologous stem cells in terms of IL-23 and a series of ligands activating acceptor proteins of the cell surface in signaling pathway of focal adhesion allows targeted influence on the interaction of glioblastoma CSCs and the intercellular matrix that limits the proliferation abilities of this type of cells and induces apoptosis (93). Cell-based products can be injected into the blood vessels of patients or incorporated into biopolymer collagen matrix implanted into the cavity of the removed tumor. In the latter case, there is a possibility for the use of a 'molecular trace' and reach tumor cells having migrated to the brain 
parenchyma by the shortest path. In addition, biopolymer matrix significantly changes the regeneration process by creating the least favorable medium for CSC reduplication.

Thus, the success of cell and post-genome technologies already allows us to start using biological drugs for the treatment of CSCs of glioblastoma. The question concerning the application of these technologies in the complex structure of GBM cannot be answered even in terms of theory. A large amount of CSCs before treatment is an unfavorable factor that requires using disintegration methods for systems including CSC-extracellular matrix and CSC-local microenvironment as a first stage of therapy which is mostly used for inoperable tumors. The obvious choice of method here could be the complex use of proteomics-based biological drugs together with cytokine therapy.

Surgery is an obligatory stage of GBM treatment. The extracted tissue is subjected to immunocytochemical and morphological analysis, and mapping of the patient genetic and epigenetic defects. Chemotherapy effectiveness can be significantly increased by prescribing medication taking into consideration the individual tumor characteristics of the patients.

CSC extraction is a strategically important stage of treatment. Comparative proteome mapping, profiling and bioinformation on CSCs and somatic stem cells of a patient are recommended for all cases while choosing proteomepersonalized cell therapy. This allows the identification of acceptor proteins in the CSC surface that are connected with intracellular pathways of signal transduction unaffected by neoplastic transformation and suitable for managing specific functions of CSCs.

\section{Conclusion}

The theory of CSCs is one of the latest advances identified by experimental oncology. As a crossing point of all modern views on carcinogenesis, the CSC theory explains the processes of dynamic modification and adaptation of tumor tissue in the case of using conventional schemes of anticancer therapy. It perfectly explains the reasons for medicinal and radiation resistance of GBM, disease relapse and generally low effectiveness of modern GBM treatment. This is why disregard for the role and significance of targeted dynamic regulation of cancer cells and the key functions of CSCs in the modern system of GBM treatment is a big oversight. Complex GBM treatment should be complemented by biomedical proteome-based cell drugs intended for managing the key functions of CSCs. These methods should be used along with modern targeted pharmaceuticals that allow management of the functions of CSCs and improvement of the survival rates of neuro-oncologic patients.

\section{Acknowledgements}

The present study was funded by a grant from the Russian Scientific Foundation (project 14-15-00084).

\section{References}

1. Torre LA, Bray F, Siegel RL, Ferlay J, Lortet-Tieulent J and Jemal A: Global cancer statistics, 2012. CA Cancer J Clin 65: $87-108,2015$
2. Siegel RL, Miller KD and Jemal A: Cancer statistics, 2015. CA Cancer J Clin 65: 5-29, 2015.

3. Smith RA, Manassaram-Baptiste D, Brooks D, Doroshenk M, Fedewa S, Saslow D, Brawley OW and Wender R: Cancer screening in the United States, 2015: A review of current American Cancer Society guidelines and current issues in cancer screening. CA Cancer J Clin 65: 30-54, 2015.

4. Louis DN, Perry A, Burger P, Ellison DW, Reifenberger G, von Deimling A, Aldape K, Brat D, Collins VP, Eberhart C, et al; International Society Of Neuropathology - Haarlem: International Society Of Neuropathology - Haarlem consensus guidelines for nervous system tumor classification and grading. Brain Phatol 24: 429-435, 2014.

5. Brodbelt A, Greenberg D, Winters T, Williams M, Vernon S and Collins VP; (UK) National Cancer Information Network Brain Tumour Group: Glioblastoma in England: 2007-2011. Eur J Cancer 51: 533-542, 2015.

6. Omuro A and DeAngelis LM: Glioblastoma and other malignant gliomas: A clinical review. JAMA 310: 1842-1850, 2013.

7. Konovalov AN, Potapov AA, Loshakov VA, Oliushin VE, Kornienko VN, Iartsev VV, Pronin IN, Korshunov AG, Golanov AV, Kobiakov GL, et al: Standards, guidelines, and options in the treatment of glial tumors of the brain in adults. $\mathrm{Zh}$ Vopr Neirokhir Im NN Burdenko 2: 3-11, 2006 (In Russian).

8. Xhumari A, Rroji A, Enesi E, Bushati T, Sallabanda Diaz K and Petrela M: Glioblastoma after AVM radiosurgery. Case report and review of the literature. Acta Neurochir 157: 889-895, 2015.

9. Greto D, Livi L, Bonomo P, Masi L, Detti B, Meattini I, Mangoni M, Doro R, Favuzza V, Cipressi S, et al: Cyberknife stereotactic radiosurgery for the re-irradiation of brain lesions: A single-centre experience. Radiol Med 119: 721-726, 2014.

10. Tsao MN, Mehta MP, Whelan TJ, Morris DE, Hayman JA, Flickinger JC, Mills M, Rogers CL and Souhami L: The American Society for Therapeutic Radiology and Oncology (ASTRO) evidence-based review of the role of radiosurgery for malignant glioma. Int J Radiat Oncol Biol Phys 63: 47-55, 2005.

11. Freund D, Zhang R, Sanders M and Newhauser W: Predictive risk of radiation induced cerebral necrosis in pediatric brain cancer patients after VMAT versus proton therapy. Cancers 7: 617-630, 2015.

12. Kamiya-Matsuoka $\mathrm{C}$ and Gilbert MR: Treating recurrent glioblastoma: An update. CNS Oncol 4: 91-104, 2015.

13. Dincoglan F, Beyzadeoglu M, Sager O, Demiral S, Gamsiz H, Uysal B, Ebruli C, Akin M, Oysul K, Sirin S, et al: Management of patients with recurrent glioblastoma using hypofractionated stereotactic radiotherapy. Tumori 101: 179-184, 2015.

14. Kickingereder P, Hamisch C, Suchorska B, Galldiks N, VisserVandewalle V, Goldbrunner R, Kocher M, Treuer H, Voges J and Ruge MI: Low-dose rate stereotactic iodine-125 brachytherapy for the treatment of inoperable primary and recurrent glioblastoma: Single-center experience with 201 cases. J Neurooncol 120: 615-623, 2014.

15. Wang B, Tanaka K, Ji B, Ono M, Fang Y, Ninomiya Y, Maruyama K, Izumi-Nakajima N, Begum N, Higuchi M, et al: Total body $100-\mathrm{mGy} \mathrm{X}$-irradiation does not induce Alzheimer's disease-like pathogenesis or memory impairment in mice. $\mathrm{J}$ Radiat Res 55: 84-96, 2014.

16. Stupp R, Mason WP, van den Bent MJ, Weller M, Fisher B, Taphoorn MJ, Belanger K, Brandes AA, Marosi C, Bogdahn U, et al; European Organisation for Research and Treatment of Cancer Brain Tumor and Radiotherapy Groups; National Cancer Institute of Canada Clinical Trials Group: Radiotherapy plus concomitant and adjuvant temozolomide for glioblastoma. $\mathrm{N}$ Engl J Med 352: 987-996, 2005.

17. Taal W, Bromberg JE and van den Bent MJ: Chemotherapy in glioma. CNS Oncol 4: 179-192, 2015.

18. Zorzan M, Giordan E, Redaelli M, Caretta A and MucignatCaretta C: Molecular targets in glioblastoma. Future Oncol 11: 1407-1420, 2015.

19. Deutsch MB, Panageas KS, Lassman AB and Deangelis LM: Steroid management in newly diagnosed glioblastoma. J Neurooncol 113: 111-116, 2013.

20. Ghiaseddin A and Peters KB: Use of bevacizumab in recurrent glioblastoma. CNS Oncol 4: 157-169, 2015.

21. Bryukhovetskyi IS, Bryukhovetskyi AS, Kumeiko VV, Mischenko PV and Khotimchenko YS: Stem cells in carcinogenesis of glioblastoma multiforme. Cell Transplant Tissue Eng 8: 13-19, 2013. 
22. Chen D: Tumor formation and drug resistance properties of human glioblastoma side population cells. Mol Med Rep 11: 4309-4314, 2015.

23. Liu Y, Zhang X, Liu J, Hou G, Zhang S and Zhang J: Everolimus in combination with letrozole inhibit human breast cancer MCF-7/ Aro stem cells via PI3K/mTOR pathway: An experimental study. Tumour Biol 35: 1275-1286, 2014.

24. Li C, Lee CJ and Simeone DM: Identification of human pancreatic cancer stem cells. Methods Mol Biol 568: 161-173, 2009.

25. Duesberg P, Mandrioli D, McCormack A and Nicholson JM: Is carcinogenesis a form of speciation? Cell Cycle 10: 2100-2114, 2011.

26. Altman J: Are new neurons formed in the brains of adult mammals? Science 135: 1127-1128, 1962.

27. Lepousez G, Nissant A and Lledo PM: Adult neurogenesis and the future of the rejuvenating brain circuits. Neuron 86: 387-401, 2015.

28. Doetsch F, Caillé I, Lim DA, García-Verdugo JM and AlvarezBuylla A: Subventricular zone astrocytes are neural stem cells in the adult mammalian brain. Cell 97: 703-716, 1999.

29. Maldonado-Soto AR, Oakley DH, Wichterle H, Stein J, Doetsch FK and Henderson CE: Stem cells in the nervous system. Am J Phys Med Rehabil 93 (Suppl 3): S132-S144, 2014.

30. Zhang S and Cui W: Sox2, a key factor in the regulation of pluripotency and neural differentiation. World J Stem Cells 6: 305-311, 2014

31. Bryukhovetskiy A, Shevchenko V, Kovalev S, Chekhonin V, Baklaushev V, Bryukhovetskiy I and Zhukova M: To the novel paradigm of proteome-based cell therapy of tumors: Through comparative proteome mapping of tumor stem cells and tissuespecific stem cells of humans. Cell Transplant 23 (Suppl 1): S151-S170, 2014.

32. Vescovi AL, Galli R and Reynolds BA: Brain tumour stem cells. Nat Rev Cancer 6: 425-436, 2006.

33. Amendola D, Nardella M, Guglielmi L, Cerquetti L, Carico E, Alesi V, Porru M, Leonetti C, Bearzi C, Rizzi R, et al: Human placenta-derived neurospheres are susceptible to transformation after extensive in vitro expansion. Stem Cell Res Ther 5: 55, 2014

34. Wu W, He Q, Li X, Zhang X, Lu A, Ge R, Zhen H, Chang AE, Li Q and Shen L: Long-term cultured human neural stem cells undergo spontaneous transformation to tumor-initiating cells. Int J Biol Sci 7: 892-901, 2011.

35. Ilkanizadeh S, Lau J, Huang M, Foster DJ, Wong R, Frantz A, Wang S, Weiss WA and Persson AI: Glial progenitors as targets for transformation in glioma. Adv Cancer Res 121: 1-65, 2014.

36. Schichor C, Albrecht V, Korte B, Buchner A, Riesenberg R, Mysliwietz J, Paron I, Motaln H, Turnšek TL, Jürchott K, et al: Mesenchymal stem cells and glioma cells form a structural as well as a functional syncytium in vitro. Exp Neurol 234: 208-219, 2012.

37. Wurmser AE and Gage FH: Stem cells: Cell fusion causes confusion. Nature 416: 485-487, 2002.

38. Friedmann-Morvinski D: Glioblastoma heterogeneity and cancer cell plasticity. Crit Rev Oncog 19: 327-336, 2014.

39. Rahman M, Reyner K, Deleyrolle L, Millette S, Azari H, Day BW Stringer BW, Boyd AW, Johns TG, Blot V, et al: Neurosphere and adherent culture conditions are equivalent for malignant glioma stem cell lines. Anat Cell Biol 48: 25-35, 2015.

40. Fine HA: New strategies in glioblastoma: Exploiting the new biology. Clin Cancer Res 21: 1984-1988, 2015.

41. Pavon LF, Marti LC, Sibov TT, Malheiros SM, Brandt RA, Cavalheiro $S$ and Gamarra LF: In vitro analysis of neurospheres derived from glioblastoma primary culture: A novel methodology paradigm. Front Neurol 4: 214, 2014.

42. Golebiewska A, Bougnaud S, Stieber D, Brons NH, Vallar L, Hertel F, Klink B, Schröck E, Bjerkvig R and Niclou SP: Side population in human glioblastoma is non-tumorigenic and characterizes brain endothelial cells. Brain 136: 1462-1475, 2013.

43. Shen G, Shen F, Shi Z, Liu W, Hu W, Zheng X, Wen L and Yang X: Identification of cancer stem-like cells in the C6 glioma cell line and the limitation of current identification methods. In Vitro Cell Dev Biol Anim 44: 280-289, 2008.

44. Neradil J and Veselska R: Nestin as a marker of cancer stem cells. Cancer Sci 106: 803-811, 2015.

45. Piccirillo SG, Binda E, Fiocco R, Vescovi AL and Shah K: Brain cancer stem cells. J Mol Med Berl 87: 1087-1095, 2009.

46. Chen R, Nishimura MC, Bumbaca SM, Kharbanda S, Forrest WF, Kasman IM, Greve JM, Soriano RH, Gilmour LL, Rivers CS, et al: A hierarchy of self-renewing tumor-initiating cell types in glioblastoma. Cancer Cell 17: 362-375, 2010.
47. Barrett LE, Granot Z, Coker C, Iavarone A, Hambardzumyan D, Holland EC, Nam HS and Benezra R: Self-renewal does not predict tumor growth potential in mouse models of high-grade glioma. Cancer Cell 21: 11-24, 2012.

48. Huang Z, Cheng L, Guryanova OA, Wu Q and Bao S: Cancer stem cells in glioblastoma - molecular signaling and therapeutic targeting. Protein Cell 1: 638-655, 2010.

49. Bryukhovetskii IS, Bryukhovetskii AS and Khotimchenko YS: New biomolecular approaches to the treatment of glioblastoma multiforme. Bull Exp Biol Med 158: 794-799, 2015.

50. Bryukhovetskiy IS, Bryukhovetskiy AS, Mischenko PV and Khotimchenko YS: The role of systemic migration and homing mechanisms of stem cells in the development of malignant tumors of the central nervous system and the development of new cancer therapies. Russian Biotherapeutic J 4: 3-12, 2013 (In Russian).

51. Bryukhovetskiy IS, Mischenko PV, Tolok EV, Zaitcev SV, Khotimchenko YS and Bryukhovetskiy AS: Directional migration of adult hematopoeitic progenitors to C6 glioma in vitro. Oncol Lett 9: 1839-1844, 2015.

52. Bryukhovetskiy IS, Bryukhovetskiy AS, Mischenko PV, et al: Migration of human hematopoietic stem cells to cells of glioblastoma line U87 in vitro. Russ Biotherapeutic J 4: 31-36, 2014.

53. Kang R, Zhang Q, Zeh HJ III, Lotze MT and Tang D: HMGB1 in cancer: Good, bad, or both? Clin Cancer Res 19: 4046-4057, 2013.

54. Bordji K, Grandval A, Cuhna-Alves L, Lechapt-Zalcman E and Bernaudin M: Hypoxia-inducible factor- $2 \alpha$ (HIF-2 $\alpha$ ), but not HIF- $1 \alpha$, is essential for hypoxic induction of class III $\beta$-tubulin expression in human glioblastoma cells. FEBS J 281: 5220-5236, 2014.

55. Moore XL, Lu J, Sun L, Zhu CJ, Tan P and Wong MC: Endothelial progenitor cells' 'homing' specificity to brain tumors. Gene Ther 11: 811-818, 2004.

56. Rolando C, Parolisi R, Boda E, Schwab ME, Rossi F and Buffo A: Distinct roles of Nogo-a and Nogo receptor 1 in the homeostatic regulation of adult neural stem cell function and neuroblast migration. J Neurosci 32: 17788-17799, 2012.

57. Aboody KS, Brown A, Rainov NG, Bower KA, Liu S, Yang W, Small JE, Herrlinger U, Ourednik V, Black PM, et al: Neural stem cells display extensive tropism for pathology in adult brain: Evidence from intracranial gliomas. Proc Natl Acad Sci USA 97: 12846-12851, 2000.

58. Aboody KS, Najbauer J, Metz MZ, D'Apuzzo M, Gutova M, Annala AJ, Synold TW, Couture LA, Blanchard S, Moats RA, et al: Neural stem cell-mediated enzyme/prodrug therapy for glioma: Preclinical studies. Sci Transl Med 5: 184ra59, 2013.

59. Schnarr K, Mooney R, Weng Y, Zhao D, Garcia E, Armstrong B, Annala AJ, Kim SU, Aboody KS and Berlin JM: Gold nanoparticle-loaded neural stem cells for photothermal ablation of cancer. Adv Healthc Mater 2: 976-982, 2013.

60. Ahmed AU, Thaci B, Alexiades NG, Han Y, Qian S, Liu F, Balyasnikova IV, Ulasov IY, Aboody KS and Lesniak MS: Neural stem cell-based cell carriers enhance therapeutic efficacy of an oncolytic adenovirus in an orthotopic mouse model of human glioblastoma. Mol Ther 19: 1714-1726, 2011.

61. Chekhonin VI, Bryukhovetskiy AS, Semenova AB, Ukhova OV and Pavlov KA: The antitumor agent based immunoliposomalnoy biological construction, its production method and vector delivery to the central nervous system with the malignancy. RF Patent 2336901. Filed August 10, 2007; issued October 27, 2008

62. Paltsev MA Ivanov AA and Severin SY: Intercellular interactions. 2nd edition, revised and supplemented. Meditsina Publishers, Moscow, p288, 2003.

63. Yang AP, Tang LT and Chen JM: Inhibitory effect of bone marrow mesenchymal stem cells on lymphoma cell proliferation. Zhongguo Shi Yan Xue Ye Xue Za Zhi 22: 1610-1615: 2014 (In Chinese).

64. Wang M, Cai J, Huang F, Zhu M, Zhang Q, Yang T, Zhang X, Qian $\mathrm{H}$ and Xu W: Pre-treatment of human umbilical cordderived mesenchymal stem cells with interleukin-6 abolishes their growth-promoting effect on gastric cancer cells. Int J Mol Med 35: 367-375, 2015.

65. Ahn JO, Chae JS, Coh YR, Jung WS, Lee HW, Shin IS, Kang SK and Youn HY: Human adipose tissue-derived mesenchymal stem cells inhibit T-cell lymphoma growth in vitro and in vivo. Anticancer Res 34: 4839-4847, 2014.

66. Bryukhovetskiy IS, Mischenko PV, Tolok EV, et al: Interaction of hematopoietic stem cells and tumor cells in vitro. Pa Med J 58: 31-37, 2014 (In Russian). 
67. He X, Li B, Shao Y, Zhao N, Hsu Y, Zhang Z and Zhu L: Cell fusion between gastric epithelial cells and mesenchymal stem cells results in epithelial-to-mesenchymal transition and malignant transformation. BMC Cancer 15: 24, 2015.

68. Sumi S and Yanai G: Fusion of mesenchymal stem cells and islet cells for cell therapy. Methods Mol Biol 1313: 107-113, 2015.

69. Aguilar PS, Baylies MK, Fleissner A, Helming L, Inoue N, Podbilewicz B, Wang H and Wong M: Genetic basis of cell-cell fusion mechanisms. Trends Genet 29: 427-437, 2013.

70. Willkomm L and Bloch W: State of the art in cell-cell fusion. Methods Mol Biol 1313: 1-19. 2015.

71. Fatima A, Hescheler J and Saric T: Chromosome tracking in fused cells by single nucleotide polymorphisms. Methods Mol Biol 1313: 95-106, 2015.

72. Bagci-Onder T, Du W, Figueiredo JL, Martinez-Quintanilla J and Shah K: Targeting breast to brain metastatic tumours with death receptor ligand expressing therapeutic stem cells. Brain 138: $1710-1721,2015$.

73. Ezzelarab M, Ezzelarab C, Wilhite T, Kumar G, Hara H, Ayares D and Cooper DK: Genetically-modified pig mesenchymal stromal cells: Xenoantigenicity and effect on human T-cell xenoresponses. Xenotransplantation 18: 183-195, 2011.

74. He HL, Liu L, Chen QH, Cai SX, Han JB, Hu SL, Chun P, Yang Y, Guo FM, Huang YZ, et al: MSCs modified with ACE2 restore endothelial function following LPS challenge by inhibiting the activation of RAS. J Cell Physiol 230: 691-701, 2015.

75. Sainathan SK, Hanna EM, Gong Q, Bishnupuri KS, Luo Q, Colonna M, White FV, Croze E, Houchen C, Anant S, et al: Granulocyte macrophage colony-stimulating factor ameliorates DSS-induced experimental colitis. Inflamm Bowel Dis 14: 88-99, 2008.

76. Najafi M, Fardid R, Hadadi G and Fardid M: The mechanisms of radiation-induced bystander effect. J Biomed Phys Eng 4 163-172, 2014

77. Marín A, Martín M, Liñán O, Alvarenga F, López $M$, Fernández L, Büchser D and Cerezo L: Bystander effects and radiotherapy. Rep Pract Oncol Radiother 20: 12-21, 2015.

78. Xiao L, Liu W, Li J, Xie Y, He M, Fu J, Jin W and Shao C: Irradiated U937 cells trigger inflammatory bystander responses in human umbilical vein endothelial cells through the p38 pathway. Radiat Res 182: 111-121, 2014.

79. Barani IJ and Larson DA: Radiation therapy of glioblastoma. Cancer Treat Res 163: 49-73, 2015.

80. Dolecek TA, Propp JM, Stroup NE and Kruchko C: CBTRUS statistical report: Primary brain and central nervous system tumors diagnosed in United States in 2005-2009. Neuro Oncol 14 (Suppl 5): v1-v49, 2012.

81. Friedmann-Morvinski D: Glioblastoma heterogeneity and cancer cell plasticity. Crit Rev Oncog 19: 327-336, 2014.
82. Labussière M, Boisselier B, Mokhtari K, Di Stefano AL, Rahimian A, Rossetto M, Ciccarino P, Saulnier O, Paterra R, Marie Y, et al: Combined analysis of TERT, EGFR, and IDH status defines distinct prognostic glioblastoma classes. Neurology 83: 1200-1206, 2014.

83. Lee JK, Joo KM, Lee J, Yoon Y and Nam DH: Targeting the epithelial to mesenchymal transition in glioblastoma: The emerging role of MET signaling. Onco Targets Ther 7: 1933-1944, 2014.

84. Lassen U, Sorensen M, Gaziel TB, Hasselbalch B and Poulsen HS: Phase II study of bevacizumab and temsirolimus combination therapy for recurrent glioblastoma multiforme. Anticancer Res 33: 1657-1660, 2013.

85. Chinnaiyan P, Won M, Wen PY, Rojiani AM, Wendland M, Dipetrillo TA, Corn BW and Mehta MP: RTOG 0913: A phase 1 study of daily everolimus (RAD001) in combination with radiation therapy and temozolomide in patients with newly diagnosed glioblastoma. Int J Radiat Oncol Biol Phys 86: 880-884, 2013.

86. Venkatesh HS, Chaumeil MM, Ward CS, Haas-Kogan DA, James CD and Ronen SM: Reduced phosphocholine and hyperpolarized lactate provide magnetic resonance biomarkers of PI3K/Akt/mTOR inhibition in glioblastoma. Neuro Oncol 14: 315-325, 2012.

87. Gardner LB, Li Q, Park MS, Flanagan WM, Semenza GL and Dang CV: Hypoxia inhibits $\mathrm{G}_{1} / \mathrm{S}$ transition through regulation of p27 expression. J Biol Chem 276: 7919-7926, 2001.

88. Goda N, Ryan HE, Khadivi B, McNulty W, Rickert RC and Johnson RS: Hypoxia-inducible factor 1alpha is essential for cell cycle arrest during hypoxia. Mol Cell Biol 23: 359-369, 2003.

89. Mjelle R, Hegre SA, Aas PA, Slupphaug G, Drabløs F, Saetrom P and Krokan HE: Cell cycle regulation of human DNA repair and chromatin remodeling genes. DNA Repair 30: 53-67, 2015.

90. Justus CR and Yang LV: GPR4 decreases B16F10 melanoma cell spreading and regulates focal adhesion dynamics through the $\mathrm{G}_{13} /$ Rho signaling pathway. Exp Cell Res 334: 100-113, 2015.

91. Xiang L, Chi T, Tang Q, Yang X, Ou M, Chen X, Yu X, Chen J, Ho RJ, Shao J, et al: A pentacyclic triterpene natural product, ursolic acid and its prodrug US597 inhibit targets within cell adhesion pathway and prevent cancer metastasis. Oncotarget 6: 9295-9312, 2015.

92. Bryukhovetskiy AS, Bryukhovetskiy IS, Shevchenko VE and Davidov MI: Antitumor individual proteome-based effective targeted cell preparation method for its preparation and using of this drug for the treatment of cancer and other malignancies. RF Patent 2335972. Filed December 24, 2012; issued October 20, 2014. 